\title{
Comunicação e pesquisa de recepção: uma perspectiva teórico-metodológica para os museus
}

\author{
Communication and reception research: $a$ \\ theoretical-methodological approach to museums
}

\author{
Marília Xavier Cury \\ Museóloga do Museu de \\ Arqueologia e Etnologia \\ Av. Prof. Almeida Prado, 14666 - \\ Cidade Universitária \\ 05508-900 São Paulo - SP Brasil
}

\author{
CURY, M. X.: Comunicação e pesquisa de recepção: uma \\ perspectiva teórico-metodológica para os museus. \\ História, Ciências, Saúde - Manguinhos, \\ v. 12 (suplemento), p. 365-80, 2005.
}

Vivemos a globalização e na aldeia global. A eletrônica permite interações sociais antes só imaginadas por prenunciadores como McLuhan. Formas de interação ou uma nova tecedura social são continuamente criadas. Uma nova ótica se instala, onde os termos em que se processam as participações na globalização e transculturação são negociados entre o local e o global. Os processos culturais colocam-se como construções múltiplas - no tempo (memória) e no espaço (multilocalizadas) -, fragmentações reestruturadas e complexificadas. Os significados culturais são construídos por indivíduos e grupos mediados por complexa rede mundializada que não separa a cultura da comunicação. Face ao exposto, a comunicação museológica e a pesquisa de recepção em exposições lidam com as formas de participação dos museus na construção dos significados culturais no mundo globalizado.

PALAVRAS-CHAVE: avaliação museológica, recepção em museus, comunicação museológica, museologia, exposição museológica.

CURY, M. X.: Communication and reception research: a theoretical-methodological approach to museums. História, Ciências, Saúde - Manguinhos, v. 12 (supplement), p. 365-80, 2005.

We are experiencing globalization, in a global village. Electronics enables social interactions previously only imagined by such prognosticators as McLuhan. Forms of interaction or a new social web are constantly being created. A new vision is taking root, where the terms according to which participation in the globalization and transculturation processes are negotiated between the local and the global levels. Cultural processes stand as multiple constructions - in time (memory) and in space (multi-located) - and as restructured fragmentations made more complex. Cultural meanings are constructed by individuals and groups mediated by a complex worldwide network that does not separate culture from communication. Accordingly, museological communication and reception research at exhibits address the ways in which museums take part in the construction of cultural meanings within our globalized world.

KEYWORDS: museological evaluation, reception at museums, museological communication, museology, museological exhibits. 


\section{Antecedentes museológicos ou respondendo às mudanças sociais}

$\mathrm{M}$

useu é lugar de coisa velha, de coisa antiga. Esta frase não surpreende os profissionais de museus, pois se refere à imagem que muitas pessoas ainda têm dessas instituições. Mas reflete uma distância entre essas instituições e a sociedade, da mesma forma que sugere que essas instituições atuam com referenciais pouco inteligíveis por serem diferentes daqueles do público.

O museu tem sua origem no colecionismo e no diletantismo e sua institucionalização foi lenta e gradual. De local reservado para expor a poucos coleções particulares, transformou-se na instituição voltada para a comunicação do patrimônio cultural preservado.

Essa evolução teve marcos, como a criação do Ashmolean Museum de Oxford, em 1683; a abertura do Louvre e do Museu de História Natural (Jardin de Plantes du Roi), na Revolução Francesa, e a criação do Conselho Internacional de Museus (ICOM) da Organização Educacional, Científica e Cultural das Nações Unidas (Unesco) após a Segunda Guerra Mundial. O ICOM/Unesco propiciou grandes avanços na mentalidade museal em resposta à demanda social do pós-guerra. Esse conselho iniciou reuniões periódicas para discutir os diversos aspectos dos museus e da museologia. Hoje, museologia é entendida como disciplina e sua cientificidade está sendo construída desde a criação do ICOM.

Peter van Mensch (1994, p. 3) mapeou essa construção a partir da revisão de documentos produzidos antes e depois da criação oficial do Comitê de Teoria Museológica do Conselho Internacional de Museus/Unesco (ICOFOM/ICOM) em 1977. O autor divide a produção teórica em museologia em cinco tipos de estudo, a saber: o estudo da finalidade e organização de museus; da implementação e integração de um conjunto de atividades visando à preservação e o uso da herança cultural e natural; dos objetos de museu; da musealidade; e da relação específica do homem com a realidade.

A última abordagem determinou a formulação da definição de museologia adotada internacionalmente. Destacamos que esta tendência da disciplina museologia, assim como a definição decorrente dela, influenciou fortemente os museólogos brasileiros, especialmente aqueles que tiveram contato direto ou indireto com as idéias

${ }^{1}$ Essa definição foi primeiramente apresentada pela autora no Encontro do ICOFOM/ICOM em Estocolmo em 1981 e pode ser consultada em Guarnieri (1981, p. 58). de Waldisa Russio Camargo Guarnieri (1990, p. 7), autora dessa definição. ${ }^{1}$ Essa pesquisadora entende que museologia é o estudo do fato museológico, ou seja, "é a relação profunda entre o Homem, sujeito que conhece, e o Objeto, parte da Realidade à qual o Homem também pertence e sobre a qual tem o poder de agir, relação esta que se processa num cenário institucionalizado, ou o museu". Para Guarnieri, essa é uma relação do homem com a cultura material mediada pelo museu, o cenário, que se dá, essencial- 
2 Pesquisa de doutorado em desenvolvimento no Departamento de Comunicações e Artes da Escola de Comunicações e Artes da Universidade de São Paulo, sob orientação da profa. dra. Maria Immacolata Vassalo de Lopes.

\footnotetext{
${ }^{3}$ A origem do temo consumo vem da economia. No entanto, essa área não logra êxito em explicar a problemática transdisciplinar do consumo cultural.
}

mente, por meio de exposições museológicas, concebidas tendo o objeto material como vetor de conhecimento, comunicação e de construção de significados culturais. A exposição, entendida como um cenário, é o meio ambiente criado e que facilita ou limita a relação do homem com a cultura material, ou seja, facilita ou limita a participação do público na vida cultural no que tange a sua relação com o objeto material.

Este estudo insere-se na quinta tendência e na definição apresentadas e pretende colaborar para o estudo da relação entre o homem o público de museus - e a cultural material em exposição mediada pelo museu, relação que se fundamenta como sendo de comunicação. O museu formula e comunica sentidos a partir de seu acervo. Esses dois atos são indissociáveis e, por isso, a área museológica e o público atribuíram a essa instituição o seu grande papel social.

Pretendemos, com esta pesquisa, ${ }^{2}$ aproximar ainda mais as áreas de museologia e comunicação, aproximação que muito enriqueceria as reflexões no campo museológico e na práxis museal. Melhor dizendo, a museologia e, em especial, a comunicação museológica pode valer-se dos avanços contemporâneos do campo da comunicação, visando à sua participação no processo de comunicação cultural - que tem a dimensão e a dinâmica comunicativa da cultura no primeiro plano. Cultura e comunicação estão imbri-cadas, assim como cultura material - que se estabelece a partir da relação dos homens com a materialidade - e comunicação em museus mediada por instituições preservacionistas.

O museu - e sua equipe de profissionais - é uma instituição produtora de exposições. Em síntese, parte do conhecimento existente sobre o acervo, desenvolve uma lógica conceitual, organiza os objetos museológicos associados a elementos contextualizadores, tendo um espaço físico como balizador dessa ordem. Cria seus modelos de representação para comunicar conhecimento. $\mathrm{O}_{\text {consumo }}^{3}$ de exposição é a possibilidade de o público de se apropriar do modelo proposto pelo museu, reelaborá-lo e recriá-lo na forma de um novo discurso. A compreensão de como o público se apropria das exposições e de como elabora os seus modelos, face ao que foi criado e produzido pelo museu, é um dos fatores motivadores desta pesquisa. Esclarecemos que o consumo, na perspectiva da recepção, será pesquisado tendo como referência os objetivos e pressupostos nos quais a equipe responsável se fundamentou para a concepção e produção da exposição como modelo de representação, entendendo o consumo como a última parte de um processo que implica seqüencialmente a criação, produção e veiculação de exposições. A pesquisa de recepção é integrada ao processo de planejamento e produção de exposições. A recepção é constitutiva da comunicação isto porque "a comunicação só se efetiva quando ela é incorporada e se torna fonte de outro discurso" (Baccega, 1998, p. 104). 
Em síntese, preocupa-nos compreender 'se' e 'como' os profissionais de museus vêm fundamentando sua práxis na área de comunicação - teoria e pesquisa de recepção - considerando que a museologia, na sua construção transdisciplinar, alimenta-se de campos de conhecimento como comunicação, educação, desenvolvimento humano, antropologia e sociologia, para citar os principais.

\section{Comunicação em museus: transformações}

Há muito fala-se em comunicação museológica e sobre o papel das exposições nessa comunicação. De fato, cabe às exposições de museus a maior responsabilidade por mediar a relação entre o homem e a cultura material. Podemos sintetizar a transformação dessa relação em três momentos. No primeiro, as exposições são concebidas por poucos e refletem uma ordem taxonômica, própria da ciência descritiva da época. São exposições que, hoje, consideradas herméticas, pois somente especialistas podem alcançar o sentido de tal lógica classificatória. Ao público restava um 'comportamento passivo' diante do exposto, visto que desconhecia os códigos científicos que regiam tal lógica.

Em um segundo momento, a ciência adquire uma postura explicativa e os museus reconhecem o seu caráter educativo. Passam, então, a planejar, conceber e produzir exposições comprometidas com 'como os museus ensinam' e 'como as pessoas aprendem'. Nesse momento, surgem as exposições interativas, aquelas comprometidas com a inteligibilidade e com a participação cognitiva do público.

O último momento consiste em exposições de última geração, aquelas em que o público é incluído como participante criativo', e os papéis de 'enunciador' (aquele que elabora o discurso, emissor) e 'enunciatário' (aquele que o recebe, receptor) tendem à sobreposição. O museu é enunciatário quando recebe e enunciador quando reelabora os múltiplos discursos sociais e cria a unicidade de seu discurso. É, então, um enunciador/enunciatário. $\mathrm{O}$ enunciatário/enunciador, o público, é enunciatário do discurso museológico e dos múltiplos discursos sociais que circulam em seu universo e enunciador quando, a partir da apropriação do discurso 'original', cria outro discurso.

As exposições de última geração, também denominadas por Padilla (1998, p. 3) como pentadimensionais por Cury (1999, p. 31-2) como hipertextuais, têm a pretensão de dissolver os papéis de enunciador e enunciatário, pois em sua estrutura essas exposições vão além da participação ao introduzirem o elemento criação. Associada à interatividade está "la posibilidad que tiene el usuario de redefinir la exhibición misma". O público, de leitor, passa a escritor, autor. Isso não significa que as posições de enunciador e 
enunciatário se anulem, e sim que serão minimizadas as relações de poder de quem tem a iniciativa e de quem recebe a mensagem expositiva. Segundo Padilla, a pentadimensionalidade é a soma das dimensões possíveis em uma exposição: a tridimensionalidade da cultura material e do espaço físico, a participação cognitiva como uma quarta dimensão e a criatividade como a quinta. Para Cury (1999, p. 31-2), a hipertextualidade refere-se à lógica hipertextual dessas exposições, ou seja, estrutura conceitual que permite múltiplas conexões por parte do público. Ao fazer as suas escolhas e traçar o seu percurso, ele escreve o seu próprio discurso, é autor e enunciador. O museu, então, é enunciatário.

O interessante desses três momentos é que um não superou o outro, isto é, eles coexistem no contexto museal atual. A constatação de que existem distintos entendimentos sobre o que é comunicação em museu e, principalmente, sobre o papel do público no processo comunicacional nos motivou a desvelar esses entendimentos face à área de comunicação.

\section{Perspectivas atuais da comunicação}

Para efeito de análise das posturas de comunicação adotadas pelos museus, adotaremos, inicialmente, duas tendências: a funcionalista e condutivista e a interacionista.

A primeira coloca o emissor e o receptor em posições assimétricas. O emissor é ativo, tem a iniciativa e produz estímulo. O receptor é passivo, é atingido pelo estímulo e reage a ele. Há, segundo esse modelo, uma relação de causa e efeito entre o emissor e o receptor, e a mensagem causa um impacto observável e suscetível de ser avaliado. O processo de comunicação pode, após essa avaliação, ser revisto e ajustado ao receptor para o alcance do 'efeito desejado'. O receptor é um indivíduo atomizado e 'puro' e participa de um processo mecânico fundamentado na idéia de que comunicação é transmissão de informações, fazer chegar uma informação de um pólo a outro.

Esse modelo considera a recepção como ponto de chegada do significado da mensagem, "no qual se encontram as intenções do emissor e suas expectativas quanto ao receptor que o espera" (Martín-Barbero, 1995, p. 40). É considerado mecênico por MartínBarbero (ibid.) e Souza (1995), por tratar a comunicação como forma de fazer chegar uma informação, do emissor ao receptor, com significado pronto, construído.

De fato, a relação de predomínio do emissor sobre o receptor é a idéia que primeiro desponta, sugerindo uma relação básica de poder, em que a associação entre passividade e receptor é evidente. Como se houvesse uma relação sempre direta, linear, unívoca e necessária de um pólo, o emissor, sobre o outro, o 
receptor; uma relação que subentende um emissor genérico, macro, sistema, rede de veículo de comunicação, e um receptor específico, indivíduo, despojado, fraco, micro, decodificador, consumidor de supérfluos; como se existissem dois pólos que necessariamente se opõem, e não eixos de um processo mais amplo e complexo, por isso mesmo, também permeado por contradições (Souza, p. 14).

O modelo citado ainda é hegemônico e dele parte a idéia de 'modelo simplificado' de comunicação, ou seja, aquele comumente esquematizado por uma seta que parte do emissor, e chega ao receptor por um meio. O feedback, ou seja, a volta da seta do receptor para o emissor, orienta o emissor para ajustes no meio para que a mensagem chegue conforme as suas expectativas. Essa concepção provoca a confusão entre o sentido do processo e as práticas de comunicação com a significação da mensagem.

No entanto, a postura de dominação unidirecional dos emissores sobre os receptores é incapaz de entender os complexos processos de interdependência entre os dois (Canclini, 1993, p. 37). Também não alcança o sentido do processo de comunicação como formulador de problemas e como possibilidade de diálogo, de negociação e de exercício de cidadania, nem rompe com a idéia de comunicação como (re)transmissão de conhecimento.

A perspectiva interacionista rompe a estrutura de setas de 'ida e volta' e o modelo dito 'simplificado', pois compreende comunicação como encontro entre os pólos que, aqui, não são entendidos como opostos. As setas, de fato, partem sucessivamente de ambos os pólos e se encontram, isto porque não há predomínio de nenhum dos dois sobre o outro. Essa perspectiva procura a interação entre a mensagem e o visitante, própria do encontro de partes que negociam o significado da mensagem. O emissor e o receptor existem, mas ambos são enunciadores e enunciatários, indivíduos e sujeitos, posto que cada uma das partes, a seu tempo, apropria-se de discursos que circulam em seu meio, reelabora-os e, então, cria os seus próprios discursos. Não há relação de poder entre o emissor e receptor, tampouco "comunicar é fazer chegar uma informação, um significado já pronto, já construído, de um pólo a outro" (Martín-Barbero, 1995, p. 40). A proposta do processo comunicacional não está na mensagem e sim na interação, espaço de encontro entre emissor e receptor, de negociação e estruturação do significado, de construção de valores e, por que não, questionamentos, diferenças e conflitos.

Comunicação como interação é entendida como complexa e articulada com a vida cotidiana. Nesse sentido, constitui-se como um conjunto de processos, e não um único, por envolver, face à globalização, múltiplas e fragmentadas mediações multilocalizadas, que produzem significações e sentidos e adquirem sentidos para 
públicos específicos, pois o público não é uma massa homogênea com comportamento constante. Constitui-se, sim, em grupos com distinções sociais que manifestam suas diferenças na recepção. Segundo Orozco-Gómes (1993, p. 272), a comunicação e a recepção perpassam uma rede complexa de germinação de informações, negociação, consumo ou negação, onde há produção de sentido e, onde, para Canclini $(1993$, p. 34) prevalece o valor simbólico sobre os valores de uso e troca.

Face ao exposto, com referência às tendências condutivista e funcionalista e a interacionista da comunicação, podemos melhor vislumbrar como a pesquisa de recepção de público pode ser planejada e desenvolvida de maneiras absolutamente distintas.

\section{Avaliação museológica e pesquisa de recepção}

A avaliação museológica é uma linha de pesquisa em museologia ampla o suficiente para abordar todos os aspectos do cotidiano museal. A bibliografia da área está sistematizada de maneira a propor abordagens para avaliação em museus.

Uma dessas abordagens refere-se ao campo de estudo chamado de estudos de visitantes (visitor studies) ou pesquisa de visitante de museu (museum visitor research), que engloba o uso que os visitantes fazem de exposições ou outras atividades ou programas públicos de museus e suas atitudes, percepções, aprendizado, motivações, comportamento e interações sociais. Para Bitgood et al. (1997, p. 6), há cinco áreas cobertas por esses estudos, quais sejam: pesquisa e desenvolvimento de público, desenho e desenvolvimento de exposições, desenho e desenvolvimento de programas, desenho de instalações em geral e serviços para o visitante.

Munley (1986, p. 19), por sua vez, apresenta a avaliação museológica em cinco grupos, organizados a partir de como pode ser compreendida no contexto institucional, a saber: justificativa do valor da instituição e/ou de seus programas específicos, conjunto de informações para ajudar o planejamento a longo prazo, auxílio na formulação de novos programas, avaliação da eficácia de programas e ampliação geral da compreensão de como as pessoas usam os museus através de processos de pesquisa e construção teórica.

Essas duas abordagens englobam as principais preocupações inerentes aos processos de avaliação museológica: o público, o mérito dos diversos programas e serviços públicos, o mérito da instituição, a adequação arquitetônica do edifício e o planejamento institucio-nal. No entanto, são distintas, com ênfases distintas. Bitgood enfatiza o público enquanto Munley, além das questões sobre o público, ressalta aquelas institucionais.

Os dois modelos demonstram preocupação em propor sistemas de avaliação que dêem conta da compreensão da realidade dos 
museus e do desejo de seus profissionais em transformar essa realidade e refinar suas ações. O sistema de comunicação museológica exige um modelo específico para sua avaliação. Para Cury (2002, p. 102), sistema de comunicação museológica é

o conjunto teórico, procedimentos metodológicos, infra-estrutura, recursos humanos e materiais, técnicas, tecnologias, políticas, informações e experiências necessários para o desenvolvimento de processos de comunicação de conhecimento por meio de exposições. Ainda, exposições como produto e a recepção por parte do público.

Para a autora, a avaliação de exposições deve ser entendida na dimensão global do processo que abrange planejamento, criação, produção, montagem, divulgação e recepção. Envolve necessariamente aspectos conceituais, metodológicos e políticos e outros que são escolhas do museu e da equipe de profissionais que nele trabalha e/ou alheios à vontade institucional e de seu pessoal. Entendemos o processo como sistema por se tratar de um todo composto por partes interdependentes que operam em sinergia, ou seja, "não deve constituir-se pela soma das características das partes, dos elementos, mas sim pela interação desses, constituindo o todo, a unidade orgânica indivisível. As características do sistema de comunicação museológica estão no todo, na sua globalidade, na sinergia" (Cury, 1999, p. 34).

Avaliar é desvelar a realidade, aprimorar ações, promover atitudes e posturas, atribuir valores. E por promover a transformação que se processa a partir da vontade institucional é entendida como a 'cultura da avaliação', que permeia a tomada de decisão em todos os níveis do trabalho em museu. Promove a reflexão sobre os dados de fato em comparação com a realidade desejada, os resultados e as intenções. Promove um juízo de valores a partir da aproximação entre o fato - o referido - e o ideal - o referente.

Assim, precisamos de um quadro teórico interpretativo complexo e crítico que transcenda aos dados empíricos sobre a avaliação do processo. Também, de uma metodologia tão complexa e crítica quanto o quadro teórico para sustentar a validade dos dados coletados, sistematizados e interpretados, seja para uma pesquisa qualitativa e/ou quantitativa.

A literatura sobre avaliação de exposições abrange diversos aspectos do sistema de comunicação museológica. Esses aspectos discriminados por diversos autores (Gottesdiener, 1997; Munley, 1987; Bitgood et al., 1997; Screven, 1990; Belcher, 1991) foram reunidos por Cury e estão apresentados a seguir.

1) Avaliação preliminar ou conceitual: ocorre na fase de planejamento, mais especificamente no momento das primeiras for- 
mulações e na definição do conteúdo da exposição. Determina conhecimento, conceitos, interesses, atitudes e preferências do público. Por avaliar idéias, é também conhecida como avaliação de conceito.

2) Avaliação formativa: ocorre durante a fase inicial de desenvolvimento do desenho da exposição e corresponde ao exame de propostas de recursos expográficos por meio de protótipos e simulação.

3) Avaliação corretiva: provoca modificações quase que imediatas à percepção de aspectos não satisfatórios da exposição.

4) Avaliação somativa: avalia a interação entre a exposição e o público, a partir do modelo museológico de comunicação proposto. Colabora para a formulação de teorias sobre como o público aprende e interage mediante determinada proposta.

5) Avaliação técnica ou apreciação crítica: é promovida e realizada pela equipe responsável pela exposição. Levanta questões técnicas não satisfatórias e o mérito do desenho da exposição. Convidados externos podem colaborar neste tipo de análise, ampliando os referenciais críticos. São avaliados os elementos expográficos do projeto e a exposição instalada.

6) Avaliação do processo: é promovida pela equipe responsável pelo desenvolvimento de determinado processo de concepção e/ou execução de exposição e visa ao refinamento das metodologias e técnicas de trabalho e de planejamento.

Cury (1999, p. 110-3) destaca que a avaliação pode ser desenvolvida pela equipe ou por convidados. A 'auto-avaliação' corresponde à vontade da equipe de conhecer e transformar a sua realidade. Com essa atitude, o museu efetiva o que se denomina como a 'cultura da avaliação'. A 'avaliação externa' é aquela desenvolvida por pessoas de fora da instituição e, por isso, menos comprometidas pelo duro cotidiano institucional, tornando-se um importante elemento de comparação, desde que essa opção seja uma decisão consciente da equipe da instituição e incorporada à política cultural interna.

De fato, o panorama apresentado não sustenta a proposição de um quadro teórico-interpretativo e de uma metodologia para coleta e sistematização dos dados empíricos, mas, certamente, esse panorama pode auxiliar na identificação do aspecto a ser avaliado e, sobretudo, na definição do objeto de estudo. 
4 Trata-se de

exposição

arqueológica,

realização do Museu

de Arqueologia e

Etnologia da

Universidade de São

Paulo (USP) e

participou da

programação dessa

universidade para as

comemorações dos

500 anos de

descobrimento do

Brasil. Foi concebida

e produzida entre

1998 e 2001 e ficou

aberta à visitação

pública entre

setembro de 2001 e

março de 2002 em

Brasília, no Superior

Tribunal de Justiça

(STJ). A autora deste

estudo coordenou as

ações museológicas

da exposição Brasil 50

Mil Anos.

5 Trata-se do projeto museológico para a

concepção, execução

e abertura para o

público de um museu

de arqueologia

regional. Foi

originado pela

pesquisa de

salvamento

arqueológico

realizada pelo Museu

de Arqueologia e

Etnologia/USP junto à

usina Agua Vermelha (responsabilidade de

Companhia de

Geração de Energia

Elétrica Tietê) no Rio

Grande, Ouroeste,

São Paulo. O projeto

museológico

institucional engloba

uma exposição, é

patrocinado pela

empresa citada e está

sob a responsabilidade

da autora desta

pesquisa.

\section{Objetivos e hipótese de trabalho}

Nossa pesquisa tem os seguintes objetivos:

1) Identificar, descrever e interpretar as diversas posturas profissionais, por meio da confrontação do que se entende como comunicação nos museus brasileiros com a área de comunicação. A aproximação da museologia e da comunicação permitirá a identificação, descrição e interpretação das posturas e a proposição de um modelo classificatório que oriente criticamente para a tomada de decisão e promova formas de interação entre exposições e o público.

2) Exercitar e discutir um modelo de comunicação museológica posto em prática por meio de exposições. A identificação, sistematização e reflexão sobre as diversas tendências brasileiras permitirão a criação de uma tendência museológica sintônica com os avanços da comunicação.

3) Exercitar e discutir um modelo metodológico para a pesquisa de recepção de público em exposições. Faz-se necessária a construção de um conhecimento teórico-metodológico que dê conta da negociação e interação que se faz entre o produtor e o público de exposições.

Trabalhamos com a hipótese de que há diferentes posturas teóricas sobre comunicação que coexistem nos museus brasileiros, mesmo que de maneira não voluntária. Este fato interfere na adoção de referenciais teóricos e metodológicos para avaliação de museus e, em especial, para a pesquisa de recepção de exposições.

\section{Quadro metodológico de referência}

A pesquisa está sendo realizada por meio da análise de três tipos de fontes:

1) A produção escrita de profissionais que se dedicam ao tema de comunicação expositiva. Utilizaremos, como base, textos publicados, anais de encontros da área museológica, produção escrita não publicada que circula e/ou disponível para consulta. Esta análise dar-se-á nas seguintes naturezas de documentos: reflexivos sobre comunicação em museus; descritivos sobre processos expositivos já concretizados; projetos expositivos; relatórios de atividades expositivas desenvolvidas; documentação sobre processos expositivos; relatórios sobre avaliação de exposição.

2) Seminários de apresentação de projetos expositivos, incluindo aqui gravações em vídeo.

3) Dois estudos de casos - a exposição Brasil 50 Mil Anos: uma viagem ao passado pré-colonial $^{4}$ e o Museu Água Vermelha. ${ }^{5}$ 
Propomo-nos a elaborar e analisar dois processos expositivos completos, o ciclo que compreende concepção, produção, veiculação e recepção.

No primeiro caso, a exposição já foi desmontada e coletaremos dados, além dos já existentes, por meio de entrevistas com os educadores da exposição. Esses profissionais permaneciam no espaço expositivo e fizeram um atendimento sistemático ao público. Possuem dados sobre o comportamento do público e, sobretudo, da forma de interação entre o público e a exposição. Esse processo possui vasta documentação, assim como artigos publicados.

No segundo caso, o processo está iniciando e poderemos propor e aplicar um estudo de recepção de público, além dos dados coletados pelo registro do processo e análise de documentos escritos. Cabe mencionar que o processo de concepção e produção da exposição será posterior à criação do Museu Água Vermelha. Isto implica entender o início do processo expositivo no início de criação do museu.

\section{A confluência de áreas}

Dado o exposto e considerando os desafios impostos pela transdisciplinaridade da museologia, entende-se que este estudo desenvolver-se-á na confluência das áreas de museologia, comunicação, estudos culturais e antropologia (e etnografia, aqui entendida como campo de conhecimento). Essa confluência define o corte conceitual e o objeto de estudo da pesquisa, assim como pretende dar conta de uma certa auto-suficiência necessária para o acercamento de princípios teóricos e metodológicos transversais, ainda inexistentes.

Considera-se que essa confluência ajudará a entender os pressupostos que norteiam os processos de concepção e produção de exposições, assim como as formas de interação do público na exposição.

\section{Dilemas e dificuldades}

As dificuldades são várias e distintas. A primeira, ou principal, consiste no fato de que museologia, comunicação e pesquisa de recepção são áreas transdisciplinares. O que deveria ser um elemento facilitador - ou outra forma de entender esses campos - torna-se uma dificuldade porque essas áreas estão em formação como transdisciplinas. Por isso, ainda se valem da interdisciplinaridade para se desenvolverem como disciplinas ou campos de conhecimento.

A antropologia, até onde temos conhecimento, não reivindica um caráter transdisciplinar, muito embora sua bibliografia faça parte da construção disciplinar de outras áreas. A etnografia, por sua 
vez, tem uma relação constitutiva com a antropologia, consistindo no campo de conhecimento auxiliar ao desenvolvimento do conhecimento antropológico. No entanto, considera-se que a etnografia, agora entendida como metodologia (e não técnica), é o que há de melhor para estudos com a perspectiva do que estamos apresentando. Entende-se, no entanto, que deve ser apropriada com uma certa parcimônia, posto que a etnografia existe em harmonia com os fundamentos da antropologia. Isto significa que a etnografia será apropriada, particularmente, no que se refere à observação, registro e interpretação de dados, ou seja, nos aspectos postos por Malinowski (1978, p. 17-34) - iniciador da observação participante na perspectiva de "estar com o outro diferente," - Sahlins (1997a, 1997b) e Marcus (1991), quanto às novas abordagens antropológicas e etnográficas face à globalização.

Cabe esclarecer que estamos, ainda, nos apropriando dos princípios e experiência de Geertz (1978), no que tange aos fundamentos etnográficos da interpretação das culturas e de suas sutilezas: tornar o estranho familiar e buscar o estranhamento do familiar. Esclarecemos que entendemos etnografia como forma de observação, a partir de diversas possibilidades: observação participante, documentos escritos, fotos, vídeos etc. Essa forma de observação da realidade não visa à mera descrição de detalhes, mas sim a compreender o universo de significações, captando o momento em que o grupo se manifesta de maneira 'real'. Essa, que é uma experiência pessoal do observador, deve gerar análises da objetivação posta, pelo pesquisador-observador, na apreensão dos fatos culturais. A transposição da etnografia da antropologia para a comunicação (pesquisa de recepção) é a segunda dificuldade que temos de enfrentar.

A terceira dificuldade no desenvolvimento deste estudo está na esparsa publicação ou produção escrita e documentação dos processos de planejamento de exposições: publicações, projetos, documentação do processo, vídeos etc. no Brasil. Essa diculdade também diz respeito à escolha do material que é realmente significativo para os nossos objetivos. Se entre a produção escrita estão os nossos 'informantes', o critério de seleção torna-se um fator de controle de qualidade das informações a serem coletadas.

A quarta dificuldade encontra-se na definição de indicadores que permitam a classificação de posturas de comunicação museológica a partir de modelos comunicacionais, uma vez que nem sempre temos autores da área de comunicação nas bibliografias da produção escrita. Assim sendo, temos de definir idéias, palavras-chave, posturas que permitam o enquadramento de dados das distintas fontes em teorias da área de comunicação.

A quinta dificuldade está no fato de que a concepção e a produção de exposições, no Brasil, é um processo lento e caro, isto por- 
que os museus brasileiros carecem de mais profissionais do que os seus quadros apresentam e, ainda, de fontes de recursos financeiros. A questão de captação de recursos para exposições ainda é um problema para as instituições museológicas. Estes problemas provocam um distanciamento entre o que se pretende com uma exibição e o que a equipe responsável logra alcançar concretamente, face à falta de recursos humanos e materiais. Precisamos levar isso em conta ao analisar os processos e estudos de casos, entendendo que nem sempre o que se consegue (o resultado) é o que se quer (a intenção), e que há razões, alheias à vontade dos profissionais de museus, para essa distância.

\section{Desdobramentos ou subprodutos}

Uma vez alcançados os objetivos propostos neste estudo, teremos subprodutos, tais como:

1) Mapear autores, instituições e/ou universidades que têm a comunicação museológica como objeto de estudo. Esse subproduto teria grande relevância para outras pesquisas que necessitassem conhecer os núcleos que se ocupam do tema no Brasil. Também promoveria o intercâmbio entre profissionais de museus brasileiros.

2) Fornecer subsídios para a formatação de projetos de exposições, de ação educativa e de avaliação.

Longe de propor um manual para as finalidades citadas, estes subprodutos demonstrariam que, apesar da complexidade, é possível e necessário o embasamento teórico e metodológico para a formatação de projetos que envolvam a produção e recepção.

\section{REFERÊNCIAS BIBLIOGRÁFICAS}

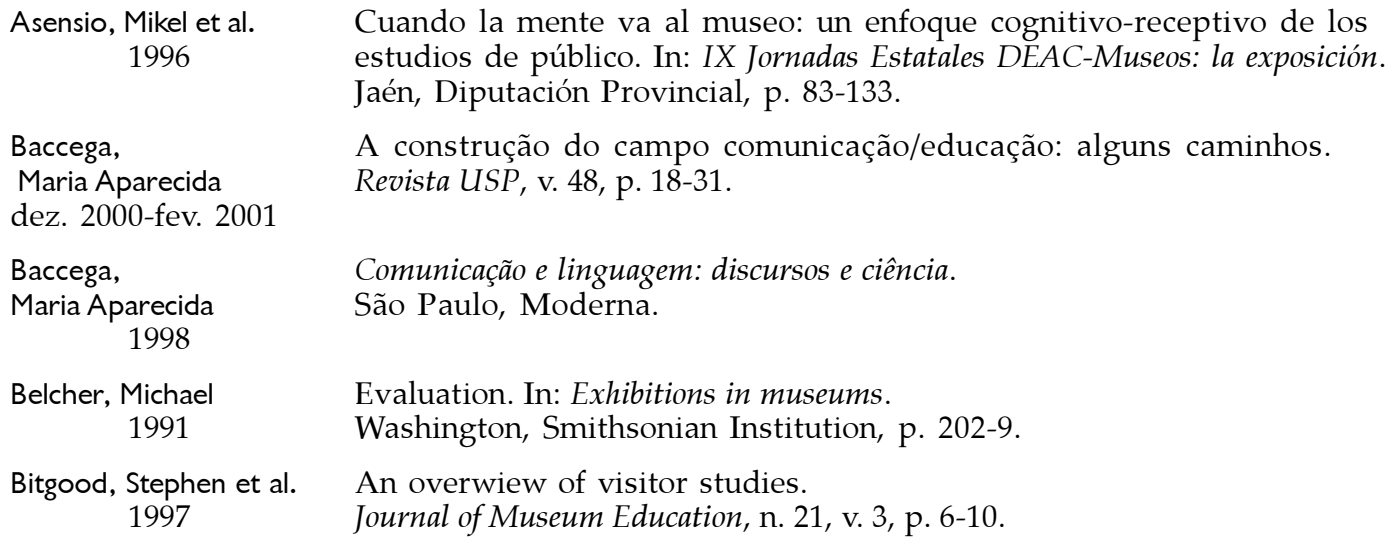

Asensio, Mikel et al. 1996

Baccega,

Maria Aparecida

dez. 2000-fev. 2001

Baccega,

Maria Aparecida

1998

Belcher, Michael

1991

Bitgood, Stephen et al. 1997

Cuando la mente va al museo: un enfoque cognitivo-receptivo de los estudios de público. In: IX Jornadas Estatales DEAC-Museos: la exposición. Jaén, Diputación Provincial, p. 83-133.

A construção do campo comunicação/educação: alguns caminhos. Revista USP, v. 48, p. 18-31.

Comunicação e linguagem: discursos e ciência.

São Paulo, Moderna.

Evaluation. In: Exhibitions in museums.

Washington, Smithsonian Institution, p. 202-9.

An overwiew of visitor studies.

Journal of Museum Education, n. 21, v. 3, p. 6-10. 


\author{
Canclini, Néstor \\ García (coord.) \\ 1993 \\ Cury, Marília Xavier \\ 2003a
}

Cury, Marília Xavier $2003 b$

Cury, Marília Xavier jan.-jun. 2002

Cury, Marília Xavier 2001

Cury, Marília Xavier 1999

Geertz, Clifford 1978

Gottesdiener, Hana 1997

Gramsci, Antonio 2000

Guarnieri, Waldisa

Russio Camargo 1990

Guarnieri, Waldisa

Russio Camargo 1981

lanni, Octávio 2000

lanni, Octávio 1997

Malinowski, Bronislaw Kasper 1978

Marcus, George 1991

Martín-Barbero, Jesús 1997

Martín-Barbero, Jesús 1995

Mensch, Peter van 1994

Miles, Roger S. 1986
El consumo cultural en México.

México, Pensar la Cultura.

O projeto museológico da exposição Brasil 50 Mil Anos. In: Cury, Marília Xavier (org.). Resumos do Encontro de Profissionais de Museus: a comunicação em questão: exposição e educação; propostas e compromissos.

São Paulo, MAE/USP/STJ, p. 45-60.

O exercício metodológico da exposição Brasil 50 Mil Anos e outras considerações. In: Cury, Marília Xavier (org.). Resumos do Encontro de Profissionais de Museus: a comunicação em questão: exposição e educação; propostas e compromissos. São Paulo, MAE/USP/STJ, p. 155-74.

Cultura da avaliação, museu e exposição museológica.

Ciências e Letras, v. 31, p. 99-116.

O partido museológico da Exposição Brasil 50 Mil Anos. In: Vasconcellos, Camilo de Mello (ed.). Brasil 50 Mil Anos: uma viagem ao passado pré-colonial (catálogo de exposição). São Paulo, MAE/Edusp, p. 53-8.

Exposição: análise metodológica do processo de concepção, montagem e avaliação. Dissertação de mestrado, São Paulo, Escola de Comunicações e Artes, USP.

A interpretação das culturas.

Rio de Janeiro, Zahar.

Evaluer l'exposition: définitions, méthodes et bibliographie sélective commentée d'études d'évaluation. Paris, La Documentation Française.

Cadernos do cárcere.

Rio de Janeiro, Civilização Brasileira, v. 3.

Conceito de cultura e sua inter-relação com o patrimônio cultural e a preservação. Cadernos Museológicos, v. 3, p. 7-12.

L'interdisciplinarité en muséologie.

MuWop/DoTraM, v. 2, p. 58-9.

Enigmas da modernidade-mundo.

Rio de Janeiro, Civilização Brasileira.

A era do globalismo.

Rio de Janeiro, Civilização Brasileira.

Argonautas do Pacífico Ocidental: um relato do empreendimento e da aventura dos nativos nos arquipélagos da Nova Guiné Melanésia.

São Paulo, Abril Cultural.

Identidades passadas, presentes e emergentes: requisitos para etnografias sobre a modernidade no final do século $\mathrm{XX}$ ao nível mundial. Revista de Antropologia, v. 34, p. 197-221.

Dos meios às mediações: comunicação, cultura e hegemonia.

Rio de Janeiro, Ed. UFRJ.

América Latina e os anos recentes: o estudo da recepção em comunicação social. In: Souza, Mauro Wilton de (org.). Sujeito, o lado oculto do receptor. São Paulo, Brasiliense, p. 39-68.

O objeto de estudo da museologia.

Rio de Janeiro, UNI-RIO, Pré-textos Museológicos 1.

Museum audiences.

The International Journal of Museum Management and Curatorship, v. 5, p. 73-80. 
Munley, Mary Ellen 1987

Munley, Mary Ellen Feb. 1986

Orozco-Gómez, Guillermo 1993

Padilla G. C., Jorge 1998

Prince, David R. 1992

Sahlins, Marshall out. 1997a

Sahlins, Marshall

Screven, C. G. 1990

Silverstone, Roger 1994

Souza, Mauro Wilton de 1995

Taylor, David

s. d.

Tirado Segura, Felipe oct. 1989

Tirado Segura, Felipe Tirado Segura, Felipe

Tirado Segura, Felipe oct. 1986

Vassalo de Lopes, Maria Immacolata et al. (coord.)

2001

Vassalo de Lopes, Maria Immacolata dez. 2000-fev. 2001

Vassalo de Lopes, Maria Immacolata jul.-dez. 1993
Intentions and accomplisments: principles of museum evaluation research. In: Blat, Jo (org.). Past meets present: essays about historic interpretation and public audiences. Washington, Smithsonian Institut Press.

Asking the right questions: evaluation and the museum mission.

Museum News, v. 64, n. 3, p. 18-23.

Cultura y televisión: de las comunidades de referencia a la produción de sentido en el proceso de recepción. In: Canclini, Néstor García (org.). El consumo cultural en México. México, Pensar la Cultura, p. 262-94.

Museos y centros de ciencia en México. Conferência proferida na $50^{\underline{a}}$ Reunião Anual da SBPC, Natal.

Approches to summative evaluation. In: Thompson, John M. A. (ed.). Manual of curatorship: a guide to museum practice. Londres, Butterworths, p. 690-700.

O pessimismo sentimental e a experiência etnográfica: porque a cultura não é um objeto em via de extinção (parte II). Mana, v. 3, n. 2

(Edição eletrônica www.scielo.br.).

O pessimismo sentimental e a experiência etnográfica: porque a cultura abr. 1997bnão é um objeto em via de extinção (parte I). Mana, v. 3, n. 1 (Edição eletrônica www.scielo.br.).

Uses of evaluation before, during and after exhibit design.

ILVS Review, v. 1, n. 2, p. 36-66.

The medium is the museum: on objects and logics in times and spaces. In: Miles, Roger; Zavala, Lauro (eds.). Towards the museum of the future: new European perspectives. Londres, Routledge, p. 161-76.

Recepção e comunicação: a busca do sujeito. In: Sousa, Mauro Wilton de (org.). Sujeito, o lado oculto do receptor. São Paulo, Editora Brasiliense, p. 13-38.

Mejorando las exhibiciones a través de la evaluación formativa.

Washington, ASTC. (mimeo.).

El Museo del Templo Mayor: aciertos y desaciertos.

Plural: Revista Cultural de Excelsior, v. 19-21, n. 217, p. 64-7.

Los custodios: un recurso educativo y de investigación para la museografía. p. 123-9. (mimeo.)

El efecto de la estrutura de integración en la experiencia museográfica. Revista Latinoamericana de Estudios Educativos, v. 17, n. 1, p. 79-97.

El plan integral de museos: la historia como guía. Información Científica y Tecnológica, México, v. 8, n. 121, p. 42-4.

Comunicación: campo y objeto de estudio. México, ITESO, Universidad Autonoma de Aguascalientes, Universidad de Colima, Universidad de Guadalajara.

O campo da comunicação: reflexões sobre seu estatuto disciplinar. Revista USP, v. 48, p. 46-57.

Estratégias metodológicas da pesquisa de recepção. Revista Brasileira de Comunicação, v. 16, n. 2, p. 78-86. 
Vassalo de Lopes,

Maria Immacolata 1990

Vergo, Peter 1994

Volkert, James W. Mar.-Apr. 1991

Wolf, Mauro 1995
Pesquisa em comunicação: formulação de um modelo metodológico. São Paulo, Loyola.

The rhetoric of display. In: Miles, Roger; Zavala, Lauro (eds.). Towards the museum of the future: new European perspectives. Londres, Routledge, p. 149-59.

Monologue to dialogue.

Museum News, v. 70, n. 2, p. 46-8.

Teorias da comunicação.

Lisboa, Editorial Presença.

Recebido para publicação em outubro de 2002.

Aprovado para publicação em maio de 2003. 